\title{
Water Pricing in Irrigation: The Lifetime of an Idea
}

\author{
F. Molle and J. Berkoff
}

\section{Irrigation Financing and Cost Recovery}

Providing irrigation always entails a measure of human labour and capital investment. In traditional small-scale systems investments were made by the communities themselves and the initial commitment generally defined rights to access water (Coward, 1980). Such undertakings were often limited (e.g. tapping a spring or a run-of-the-river diversion using a few stones or logs laid across a small stream) but could also be quite costly (as in the case of qanats, underground drainage galleries commonly dug over several kilometres). Larger-scale ventures were financed directly by rulers (e.g. river diversions in Mesopotamia or large tanks in South Asia) who derived economic surpluses from the increased production.

The view of irrigated agriculture as a means of ensuring both population needs and generating returns to capital was made explicit during colonial times. Investments in irrigation by the British in Sudan, Egypt, India and Sri Lanka, for example, are all well documented, and income generation and profitability were central concerns. Farmer (1976) observed that in Sri Lanka 'the English government was always concerned, and sometimes obsessed, by the protection and the increase of its income, as was the case in other colonial territory'.
Colonial administrators sought both to protect and to uplift the poor masses, when considered to be in a state of misery, and involve them in productive capitalistic investments that would yield net revenues to the Crown (Bastiampillai, 1967). ${ }^{1}$ Stone (1984) also documented the endless debates between supporters of irrigation and the guardians of the royal purse.

In contrast to narratives which assume that a focus on the economic value of water was characteristic of a late phase of water resources development, British colonial documents clearly show that most questions currently debated on the economics - perhaps more accurately the financing - of irrigation were already centre stage. The questions of who was to finance the infrastructure (local revenue, the Crown, or private interests), whether and how a water fee should be levied, what its impact on different categories of people would be, whether it should be increased, whether it could influence crop choice or water use behaviour, to cite a few examples, were fiercely debated. Opinions

\footnotetext{
${ }^{1}$ For example, arguing for investments in the south of Sri Lanka, a British administrator referred to the 'magnificent and really noble and philanthropic, enterprise [to be] accomplished. Nor will it be a barren philanthropy, I mean, in point of pecuniary profit even' (Steele, 1867).
} 
diverged between the British Government, the Government of India and other colonial authorities, local governments, canal engineers, etc., and alternatives such as private investments, bulk volumetric pricing and crop-based differential rates were all tested (Bolding et al., 1995).

The financial (or economic) view of irrigation lost its prominence in the four decades following World War II. Irrigation and dams became pivotal investment options for developing countries, notably newly independent states, to deliver on the promise of feeding the masses, providing income opportunities to rural populations, balancing regional development and alleviating poverty, and hence building self-sufficiency and state legitimacy. Development was seen largely as a matter of infrastructure and technical transfer, and large dams, irrigation schemes, flood control structures and other water projects received massive capital outlays (see Molle and Berkoff, Chapter 2, this volume, and Molden et al., 2007). The national, as well as geopolitical, interests vested in such investments and in the increase in lending by development banks contributed to an outburst of projects, frequently undertaken on political rather than on sound economic grounds (Barker and Molle, 2004). Cost-benefit analyses often remained shoddy and there was limited scrutiny on the assumptions and projections made. All parties involved (governments, local politicians, consultants, construction firms, lending agencies, etc.) had incentives to go ahead (Repetto, 1986; Molle and Renwick, 2005), while the concerned populations were most of the time considered mere recipients of projects rather than partners in their own development. Whether politicians and engineers were infected by the 'desert bloom' syndrome (Carruthers and Clarck, 1981), fulfilled a 'hydraulic mission' through politically rewarding iconic megaprojects or aimed to revitalize an impoverished countryside, free land and water resources were seen as the basic material of agricultural development.

These investments yielded mixed results. Although much was achieved, land productivity, distribution efficiency and management often remained suboptimal, economic returns were often disappointing and environmental externalities (salinization, waterlogging) became more evident with time. Technology alone proved unfit to deal with these growing challenges and attention shifted to organizational aspects, including farmers' participation, turnover and capacity-building. Initially, the World Bank funded only new projects, but poor performance led to a policy shift towards rehabilitation in the late 1960s (Jones, 1995). A first operational policy memorandum (OPM 2.61), issued in 1971, stated that the recovery of all project costs was a normal aim but offered a loophole by adding that 'as a minimum, operation and maintenance costs should be recovered completely' (Jones, 1995). During the 1970s, the questions of why charge, and whom and how much to charge, for water stirred much debate at the World Bank. Proponents of irrigation lending and engineers perceived policy instructions as interference in their job. The prevailing philosophy remained that of 1971, though it was recognized that investment costs might be too high for beneficiaries to pay back and that a 'reasonable' share would be acceptable. Covenant language was accordingly often vague ( $\$$. . to the extent practicable' or '.. . as much as possible') and there was virtually no capital cost recovery (Duane, 1986). An earlier study (W.A. Wapenhans, IBRD, 1969, unpublished data) had shown that 17 projects completed in the 1960s had estimated levels of charge collection that exceeded operation and maintenance (O\&M) but only amounted to $29 \%$ of full costs.

In 1976, an 'informal discussion paper to assist staff in developing satisfactory approaches to cost recovery' (Ray et al., 1976), followed by Central Projects Memorandum No. 8.4 (World Bank, 1976), defined new overall policy principles and guidelines, stressing three objectives as the basis for cost recovery: public savings, income distribution and economic efficiency. The objective of public savings was to 'enable governments to undertake additional rural development projects that would reach a larger number of the rural poor'. It was also recognized that recovery of all costs might not be possible and that 
the poor should be identified and exempted. ${ }^{2}$ 'Efficiency pricing of irrigation water is usually not possible' but 'even a nominal price for water would offer users some incentive to eliminate at least some of the conspicuous waste and overwatering . . . which occurs when water is treated as a free good' (Ray et al., 1976). Volumetric pricing was desirable but, if not practical, a benefit tax (linked to the land tax), 'although constrained by various administrative and political factors', should be considered a second-best option.

In 1981, the Operations Evaluation Department (OED) released an analysis of 26 irrigation projects completed in the 1970 s (World Bank, 1981). Aside from severe problems with water management and maintenance, the survey found that cost recovery covenants had been breached in 11 cases, with no or limited water charges. Reasons included reluctance by government to reduce farm income, cultural or religious resistance, the political clout of farmers and a common 'operational' constraint: 'If project management cannot guarantee continuous and adequate water deliveries to most, or all, project beneficiaries, the Government becomes liable.' While, on the one hand, insufficient attention had been given to differing local conditions, on the other, large discrepancies in the way the Bank handled negotiations with different countries could not be explained by the policy guidelines. Lastly, no relation was found between charges and irrigation efficiency and 'factors, other than water charges, always proved to be much more important in explaining farmer behaviour than the presence, absence or absolute cost of water charges' (World Bank, 1981).

Application of the guidelines ${ }^{3}$ in different countries proved difficult. In Indonesia, reinvestment of charges in O\&M was hindered by a fiscal problem of flow of funds between central, provincial and local governments, and

\footnotetext{
${ }^{2}$ It was proposed that an 'indicator of benefits' taken as the incremental gross value minus all incremental costs (irrigation service fees or their equivalent not considered) should be used. Farmers below a critical consumption level (CCL) to be defined would not be taxed.

${ }^{3}$ Reissued with minor changes in 1980 under Central Project Note No. 2.10 (World Bank, 1980).
}

the willingness to pay was affected by quality of service and by a taxation on rice amounting to $37 \%$ of the world price (D. Thompson, World Bank, 1982, unpublished data); in Bangladeshirrigation remained heavily subsidized with benefits accruing to the 'better off' (World Bank, 1978); in some countries studies on farmers' ability to pay were made at the Bank's insistence but their conclusions were disregarded (World Bank, 1981).

The 1976 policy was broadened and simplified in a Policy Note (World Bank, 1984), informed by yet another survey on cost recovery performance. This note distinguished between resource mobilization and allocation and emphasized again the failure to fund O\&M, regardless of how much was recovered. It was proposed that assurances should be sought of adequate funds for O\&M as a substitute for demanding cost recovery but this was edited out of the final text (Jones, 1995). The lack of incentive for non-autonomous agencies to collect fees or improve management, inadequate collection mechanisms and transaction costs of collecting fees (especially if they were to be volumetric) were listed as constraints. Although the 'longer term objective to have a system of resource mobilization that will recover capital costs so permitting replicability of investments' (World Bank, 1984) remained, most Bank economists were incensed by the weakening of the principle of long-term marginal cost pricing (Jones, 1995).

A further review of conditionality and cost recovery in 1986 confirmed that in only about $15 \%$ of irrigation projects were loan covenants fully met and that recovery rates ranged from $0 \%$ to $100 \%$ of O\&M costs, with most in the range of $15-45 \%$ (World Bank, 1986). Limited adherence to covenants was ascribed to: (i) the lack of government commitment; (ii) unreliable water supply due to poor O\&M of irrigation systems; and (iii) the often heavy burden of direct and indirect taxes already imposed on the farming sector (World Bank, 1986). ${ }^{4}$ The lack of relation

${ }^{4}$ Preliminary results of the study of the political economy of agricultural policy by Krueger et al. (1988, 1991), as well as the review by Small et al. (1986), seem to have been influential in bringing this issue to the fore. 
between recovery and O\&M effectiveness questioned the Bank's emphasis on cost recovery, with Duane (1986) considering the Bank's approach as 'heavily influenced by its thinking about authorities supplying public utilities such as electricity, water for domestic use, etc. which were expected to be selfsustained by commercial revenues'.

The Bank policy had to come to terms with the fact that countries such as India or Thailand were clearly opposed to direct charges, either because irrigation was targeted towards the rural poor and was not expected to be self-sustaining or generate revenue, or because price distortions already siphoned off much of the agricultural surplus (Mexico, Thailand, Sri Lanka, Indonesia, Egypt, etc.) (Duane, 1986; Krueger et al., 1988, 1991; Small, 1990). In 1986, the Asian Development Bank (ADB) also carried out an evaluation of its irrigation projects and came to conclusions similar to those of the World Bank's 1981 review (ADB, 1986a). In most cases, executing agencies had remained in complete or partial default of irrigation service fee covenants.

\section{Management and Cost Recovery}

Despite these disappointing reviews, 1986 was notable for a growing consensus that coalesced in a number of converging analyses of the role of irrigation service fees and their relationship to other mechanisms for improving irrigation performance. A World Bank study, for instance, condensed ideas collected from a few country-level analyses and concluded that it is time to take a more pragmatic and comprehensive approach to this issue' (World Bank, 1986); the ADB held a regional seminar (ADB, 1986b) and commissioned the International Irrigation Management Institute to carry out a regional study (Small et al., 1986). Concurrently, US Agency for International Development (USAID) commissioned a report on 'Irrigation pricing and management' (Carruthers et al., 1985), and FAO and USAID (1986) conducted an expert consultation on irrigation water charges.
Several subsequent papers and reports were consonant with these views (e.g. Moore, 1989; Sampath, 1992; Vaidyanathan, ${ }^{5}$ 1992), which were eventually summed up in a remarkable book on irrigation financing by Small and Carruthers (1991).

Although emphasis differed, there was general agreement that water charges alone were an inadequate mechanism for improving irrigation performance and that primacy needed to be given to water distribution and control. Staff members of development banks acknowledged that 'an element of subsidy in irrigation projects is not necessarily sub-optimal' (Ghate, 1985) and that 'bidding for water should not be promoted' (Frederiksen, 1986). The following list by and large summarizes this consensus:

1. The primacy of management. Irrigation water charges influence individual farmer behaviour in only a very few on-demand systems. By far the most important mechanism for achieving rational water use is by careful control of distribution and by allocations that broadly meet crop requirements. Fee policies have little or no impact on irrigation system performance (Svendsen, 1986).

2. Control of supply a prerequisite. 'Many of the frequently cited inefficiencies of water use in irrigation projects stem more from inadequate control over the distribution of the supply of water than from failure to regulated demand through prices. Supply control can reduce wastage of water associated with excess amounts of water flowing through uncontrolled canals and ungated turnouts onto fields and into drainage channels. It may also encourage more efficient use of water at the farm level by imposing a degree of water scarcity on the farmers. A substantial portion of the large efficiency gains which are sometimes expected from a demand-based pricing system would thus most probably be realized by implementation of the prerequisite supply control' (Small et al., 1986).

${ }^{5}$ In 1992, a Committee on Pricing of Irrigation Water headed by Professor Vaidyanathan (1992) issued a report to the Planning Commission of the Government of India with recommendations regarding the pricing of irrigation water in India. 
3. Financial autonomy. 'The way in which fees are assessed, collected and expended is more important than the actual level of fees in improving system efficiency and effectiveness. The most critical factor is the level of fiscal autonomy of the irrigation agency, i.e. the extent to which the level of its operating budget is tied to the amount of revenue generated by irrigation systems operations. This provides an incentive for cost-effective goaloriented performance that is otherwise often weak or lacking' (FAO and USAID, 1986).

4. Contextualized cost recovery. The principle of charging for water should be contextualized to consider ability to pay and the overall taxation of agriculture, indirect charges often providing an indirect (but straightforward) means to recover investment costs. Cost of collection needs to be evaluated carefully, price structures tailored to the particular situation and prices indexed. The evaluation of what should be the ideal level of O\&M activities should receive more attention.

5. A contribution principle. Subsidized water users should repay some of the investments but they should not be asked to repay the cost of 'over-elaborate gold-plated designs, incompetent, expensive construction, cost overruns for reasons of corruption, bad scheduling of construction activities or the like, nor overmanning of the public sector' ${ }^{6}$ While making farmers pay for O\&M costs is achievable in most cases, in very few projects (if any) would farm revenues be enough to repay investment costs.

The exception to this consensus was Repetto's (1986) discordant but influential paper on rent-seeking and the performance of public irrigation schemes, which heralded the coming critiques of the 1986 consensus. Repetto convincingly showed how the design and development of irrigation projects were influenced by rent-seeking strategies. From this, he concluded that there was little virtue in objectives other than economic viability, advocating that irrigation projects should be

${ }^{6}$ Rao (1984) estimated that in India only about half of the officially estimated costs should be taken as real costs. considered as normal investments requiring recovery of full costs, without considering secondary benefits. His analysis of pricing as a means to improve management, however, proved to be weaker: it shrugged off the constraints pointed to by the other studies and extrapolated particular cases, such as private irrigation schemes, to support the generalization of full volumetric pricing and the trading of water rights. Repetto endorsed the model of financial autonomy but in the narrow sense of the utility model, without flagging the difficulties inherent in water allocation and distribution in large-scale surface hydraulic systems.

Repetto's analysis coincided with a growing awareness in the 1980s and early 1990s, in the wake of financial crises and structural adjustment programmes, of the burden on government finances inherited from everexpanding schemes of dubious profitability. Several countries including the Philippines, Mexico, Morocco, China and Turkey, opted for reforms primarily aimed at shifting part of the O\&M burden to the farmers, blended with varying degrees of transfer of management responsibility (see Molle and Berkoff, Chapter 2 , this volume). These experiences were sometimes influential but failed to launch a wider dynamic that would have embodied and imposed the principles identified.

At the Bank, the debate was not interrupted by the series of documents issued in the 1980s. The decade ended with a renewed attempt to clarify issues and break away from past confusion; several mistakes from the past were acknowledged (e.g. 'zeal for the fiscal autonomy model' has been insensitive to borrowers' policies and the 'single-minded application [of the model] ${ }^{7}$ to a second-best world' might not be adequate; establishing boundaries between poor and other farmers to

\footnotetext{
${ }^{7}$ According to Small (1990) the banks' constant concern for cost recovery (despite the fact that payment of loans is guaranteed by governments) is linked to 'a misplaced concern stemming from the importance of cost recovery in private investments, where the inflow of funds to the investor represents the return on the investment. But it is inappropriate to place the same meaning on cost recovery in the case of public investments.'
} 
be charged is 'unworkable') (O’Mara, 1990). On the other hand, emphasis was put again on the priority to be given to physical sustainability, on accepting 'the diversity of cultures and institutional arrangements in borrowing countries' and on basing cost recovery policy on a full analysis of government interventions (O’Mara, 1990). ${ }^{8}$

\section{Water Pricing and Economic Incentives}

Although the ideas can be traced back to earlier periods, 1992 marks a convenient turning point in the debate on water pricing: in 1992, the Dublin International Conference on Water and the Environment proposed a set of four principles, the fourth ${ }^{9}$ of which underscored that 'managing water as an economic good is an important way of achieving efficient and equitable use, and of encouraging conservation and protection of water resources'. Although, as seen above, there was nothing novel in the concern with financial profitability, the fourth Dublin principle can be considered a landmark shift in emphasis to the economic dimensions of water use in general and irrigation development in particular. Economic instruments and the economic value of natural resources further

${ }^{8} \mathrm{O}^{\prime}$ Mara, Principal Economist at the Agricultural Policies Division (ARD Department), offered his paper as a 'modest effort to clear away the confusion surrounding irrigation policy both inside and outside of the Bank. That there is a need for a policy dialogue within the institution on this topic is increasingly apparent. In its present form, the paper reflects the comments and criticism of many Bank staff concerned with irrigation.'

${ }^{9}$ The full principle reads: Principle No. 4: Water has an economic value in all its competing uses and should be recognized as an economic good. Within this principle, it is vital to recognize first the basic right of all human beings to have access to clean water and sanitation at an affordable price. Past failure to recognize the economic value of water has led to wasteful and environmentally damaging uses of the resource. Managing water as an economic good is an important way of achieving efficient and equitable use, and of encouraging conservation and protection of water resources. found legitimacy in the Rio Declaration on Environment and Development of the United Nations in 1992 (EU, 2000) and its Agenda 21 (United Nations, 1992), ${ }^{10}$ which supported the 'implementation of allocation decisions through demand management, pricing mechanisms and regulatory measures'.

More generally, the early 1990s saw the rise of the concept of demand management (which can be defined by 'doing better with what we have' as opposed to continuous supply augmentation), mostly under the influence of resource economists stressing both the economic nonsense of privileging costly and environmentally unfriendly water resources development, and the role and potential of economic incentives in managing demand and reducing the need for additional supplies. The emphasis put on economic efficiency and on the 'user-pay' and 'polluter-pay' principles struck sensitive cords and ushered in heated debates on the right to water, the respective roles of the private sector and local communities, and how to interpret and reconcile the economic and sociocultural dimensions of water.

Conceptually, this period distinguishes itself from the preceding one by a shift in emphasis (Maestu, 2001): earlier justifications of charging for water centred on the financial need for cost recovery to fund further projects (equity), relieve state finances and ensure the physical integrity of, and continued benefits from, irrigation schemes. In the 1990s, water prices, and more generally economic incentives, came to be seen as key policy tools endowed with the potential

${ }^{10}$ Principle 16 of the declaration reads: National authorities should endeavour to promote the internalization of environmental costs and the use of economic instruments, taking into account the approach that the polluter should, in principle, bear the cost of pollution, with due regard to the public interest and without distorting international trade and investment.' More importantly, Chapter 18 of Agenda 21 stresses: 'Implementation of allocation decisions through demand management, pricing mechanisms and regulatory measures... [p]romotion of schemes for rational water use through public awareness-raising, educational programmes and levying of water tariffs and other economic instruments.' 
to achieve multiple objectives. With demand management-oriented approaches making conservation a critical issue, the conventional role of prices in managing demand moved from the back seat to centre stage. Likewise, increasing intersectoral competition for water and associated environmental externalities made pricing mechanisms appear as a potential and desirable means to arbitrate water allocation ${ }^{11}$ and promote desirable environmental objectives, while maximizing water productivity and aggregate economic welfare. Assigning all these roles to pricing could be seen as the embodiment of the Dublin principle stressing the economic nature of water.

Given this anticipated potential for ensuring financial autonomy of the irrigation sector, cutting state expenditures, eliciting water savings and maximizing the economic efficiency of water use across society, water pricing understandingly attracted increasing attention from policy makers, academics, development agencies and banks (OECD, 1999b). With so much frustration generated by the need for repeated rehabilitation (in Indonesia, for example, one-third of the 3 million ha of government-designed irrigation schemes has been rehabilitated twice in the last 25 years; World Bank, 2005a), by failed attempts to improve water management or efficiency substantially and by incomplete turnover of management to farmers, price instruments appeared to hold the promise of promoting several desired policy goals. In addition, they would provide an elegant solution to long-standing problems, changing behaviour directly through incentives, thus seemingly avoiding the painstaking intricacies of irrigation management, and its technical, social and political ramifications.

This economic rationale soon percolated to water policies. The World Bank's Water

\footnotetext{
${ }^{11}$ In 1985, concern was only expressed for 'the efficient level of use of scarce water and to its allocation to crops where returns to irrigation are higher', not for sectoral allocation (see Ghate (1985) for ADB's point of view). In the EU 'it is only in the early 1990s that attention started switching to the economic value of water' (EU-WATECO, 2003).
}

Resource Management Policy Paper of $1993^{12}$ observed that 'waste and inefficiencies have resulted from the frequent failure to use prices and other instruments to manage demand and guide allocation', and established a powerful narrative around the overarching causal link between water crises, water waste and underpricing. Subsequently, the Bank's policy paper remarked that the value of water differed greatly between agriculture and other sectors, 'often indicating gross misallocations if judged by economic criteria'. It followed that 'setting prices at the right level is not enough; prices need to be paid if they are to enhance the efficient allocation of resources' (World Bank, 1993).$^{13}$ Besides continuing to ensure basic cost recovery, price mechanisms were thus assigned the further objectives of reducing water waste, minimizing environmental damage and reallocating water towards higher uses.

The 1990s saw a flourishing literature on the theoretical principles and potential impacts of pricing and water markets, with a leading contribution from the World Bank. ${ }^{14}$ During a press conference in Washington on 12 April 2000, James D. Wolfensohn (2000), President of the World Bank, reiterated the view that 'the biggest problem with water is the waste of water through lack of charging'. Johansson (2000) saw water pricing as a 'primary means ... to improve water allocations

\footnotetext{
${ }^{12}$ Jones (1995) reports that the elaboration of the paper saw a renewed conflict between economic orthodoxy bent on the long-term marginal-value pricing principle and the view defended by operating divisions, Agriculture Department staff and consultants, who advocated more flexibility.

${ }^{13}$ Identification of an 'allocation stress' became commonplace. For instance, Dinar (1998) held that 'the potential for economic benefits from allocationoriented institutional change are not only substantial but also increasing with each increase in water scarcity'. Rosegrant and Cline (2002) posited that 'there is considerable scope for water savings and economic gains through water reallocation to highervalue uses'.

${ }^{14}$ See, for example, Teerink and Nakashima (1993); Le Moigne et al. (1994); Tsur and Dinar (1995); Bhatia et al. (1995); Thobani (1997); Dinar and Subramanian (1997); Easter et al. (1998, 1999); Dinar (2000); Johansson (2000); and AMAECO and ANAFID (2002).
} 
and to encourage conservation'. The Economic and Social Commission for AsiaPacific (ESCAP, 1996a,b) ${ }^{15}$ saw pricing as an 'essential component of water demand management', which could in particular 'significantly reduce the wastage of resources'. $\mathrm{ADB}$, in its 2000 water policy, reaffirmed that it 'needs to promote efficiencies in water use by supporting demand management, including water pricing'. Jones (2003) stated that 'anything scarce and in demand commands a price', and that consequently 'water pricing is increasingly seen as an acceptable instrument of public policy'. Finally, the World Water Commission's (2000) report proclaimed that 'the single most immediate and important measure that we can recommend is the systematic adoption of full-cost pricing for water services', although acknowledging that full-cost pricing, long advocated in the irrigation sector, 'has seldom happened'. Other UN organizations and development banks, such as ESCWA (1997, 2005), ESCAP (1981), and AfDB and ADF (2000), ${ }^{16}$ usually reproduced these principles and objectives, most of them underscoring cost recovery, but some including the IADB (1998) and CEPAL (1995) - putting their emphasis on decentralization, water rights and water markets.

These views were consonant with, and perhaps partly derived from, policy shifts in developed countries. The late 1990s saw the gradual elaboration of the European Water Framework Directive which put eco-

\footnotetext{
${ }^{15}$ If properly set and implemented, water pricing for agricultural water could significantly reduce the wastage of resources (ESCAP 1996a). 'Water pricing is an essential component of water demand management which is instrumental in achieving two important goals: to generate revenue for capital recovery, operation and maintenance, extension of the system; to promote efficiency in use; and to protect the quality of water resources by reducing the wastewater discharge' (ESCAP, 1996b).

${ }^{16} \mathrm{AfDB}$ and ADF (2000), for example, reads like a textbook of ideal principles, peppered with realism, such as: 'Ultimately, the aim of water pricing should be economic cost recovery, taking into account social equity and capacity to pay by the rural and urban poor. Initially, however, RMCs should target the recovery of full financial costs.'
}

nomic incentives in general and pricing policies in particular at the heart of its objectives of financial and environmental sustainability ${ }^{17}$ (seeOECD, 1999a, 2002;EuropeanCommission, 2000a,b). Interestingly, the use of pricing in the EU policy is advocated primarily as a conservational means to manage demand so as to curb excessive abstraction of water from ecosystems, and incorporates the polluter-pay principle, with water charges being instrumental in internalizing environmental costs. This reflects the weight of environmentalism in promoting economic incentives as key tools for water policy (de Moor and Calami, 1997; Avis et al., 2000; Kaika, 2003; Khanna and Sheng, 2000). In contrast, official references to the sectoral allocation and to charging opportunity costs are rare, although some environmentalists regard full-cost pricing as a way of decreasing demand and environmental damage, since 'the price [of water] could be raised until the level of demand was consistent with the environmental constraints on supply' (Hodge and Adams, 1997), and since 'full cost recovery for water services (should) include the costs of damages to the environment' (Avis et al., 2000).

Numerous analysts have embraced the concept of demand management (Frederick, 1993; Hamdy et al., 1995; Brooks, 1997; Winpenny, 1997; Ahmad, 2000; Louw and Kassier, 2002), seeing its application as a primary means to solve the current water crisis. In turn, central ideas such as the persistence of massive water losses in the agriculture sector, poor management and misallocation of water resources, and the crucial role of economic incentives made their way into the mainstream media including The Economist (2003), Scientific American (Gleick, 2001), Science (Gleick, 2003) and National Geographic (Frank,

\footnotetext{
${ }^{17}$ The 'proposed Water Framework Directive promotes the use of water charging to act as an incentive for the sustainable use of water resources and to recover the costs of water services by economic sector. This will contribute to meeting the environmental objectives of this directive in a cost-effective way' (European Commission, 2000b).
} 
2001). Spurred by the Second and Third World Water Forums, newspapers and analysts also echoed prophecies of the 'coming' (Lavelle and Kurlantzick, 2002), 'creeping' (Falkenmark, 2001), 'impending' (Rosegrant et al., 2002) or 'looming' (IRRI, 1995; UNESCO, 2000) water crises.

These ideas trickled down to policy and law-making in many countries. The 1998 South African Water Act specifies that 'water use charges are to be used to fund the direct and related costs of water resource management, development and use, and may also be used to achieve an equitable and efficient allocation of water' (Republic of South Africa, 1998). ${ }^{18}$ Article 19 of the 1997 Brazilian Water law recognizes water as an economic good and introduces water fees with the triple objective of indicating the value of water, rationalizing the use of water and levying funds for the further development of water resources (Government of Brazil, 1997). The 1999 National Water Policy of Bangladesh states that '[a] system of cost recovery, pricing, and economic incentives/disincentives is necessary to balance the demand and supply of water' and that 'water will be considered an economic resource and priced to convey its scarcity value to all users and provide motivation for its conservation' (Government of Bangladesh, 1999; Chakravorty, 2004). Many other state policies or legal acts ${ }^{19}$ include similar general principles, or focus on particular ones, such as cost recovery in the case of Vietnam (1998) (users have a 'financial duty and the duty to contribute manpower and budget'), or of the 1988 Law

\footnotetext{
${ }^{18}$ In addition, they may also be used to ensure compliance with prescribed standards and water management practices according to the user-pay and polluter-pay principles. Water use charges will be used as a means of encouraging reduction in waste, and provision is made for incentives for effective and efficient water use.

${ }^{19}$ This is not the case, however, for all national laws and policies. India (GOI, 2002), Pakistan (GOP, 2002) and Malaysia (FAO, 1996a), for example, do not see irrigation pricing as a water management and policy instrument.
}

of China (as well as succeeding draft versions of its revision). ${ }^{20}$

The apparent overwhelming ${ }^{21}$ adoption of pricing principles created an intellectual environment which made it somewhat difficult for alternative or nuanced voices to be heard. Several papers looking critically at the issue were published ${ }^{22}$ and several reviews were carried out though they did not significantly alter the debate. ${ }^{23}$ An OED study (Jones,

${ }^{20}$ Article 42 stipulates: 'Those who use water provided by water supply projects shall pay water charge to the supplying unit in accordance with stipulations. Water price shall be defined as per the principles of cost recovery, reasonable profit, and good price for good quality and fair shares. The system of accumulative pricing shall be conducted to the water use over than the planned amount.'

${ }^{21}$ Many papers emphasized the emergence of a consensus and the alleged growing application of such principles, contributing to create a 'policy bubble'. See, for example, Johansson et al. (2002): 'In addressing water scarcity and increased population pressures many countries are adopting waterpricing mechanisms as their primary means to regulate irrigation water consumption'; Saleth (2001): 'Although water continues to be subsidized in most sectors and countries, there is growing recognition of water pricing as a key policy instrument for cost recovery and demand management'; Jones (2003): 'Water pricing is increasingly seen as an acceptable instrument of public policy.' While these statements are correct in the narrow sense that economic and financial concerns have become more salient and incorporated in policies, they tend to convey an overly optimistic view that economic instruments will be both paramount and effective in achieving multiple long-sought goals.

${ }^{22}$ See, for example, Carruthers and Morrisson (1996), Morris (1996), Perry (1996, 2001a,b), Chaudhry et al. (1993) and Perry et al. (1997).

${ }^{23}$ For a number of economists, the question was no longer the desirability or possibility of using price regulation but a mere technical debate on how to determine the 'optimal price', for example: 'Despite the pervasiveness of water pricing as a means to allocate water, there is still disagreement regarding the appropriate means by which to derive the price' (Johansson et al., 2002; see Kim and Schaible, 2000; Louw and Kassier, 2002). That prices based on concepts of marginal costs or opportunity costs are invariably found to be incompatible with maintaining farm revenues does not seem to have triggered much theoretical debate. 
1995) on 'the World Bank and irrigation' questioned the 'Bank's enthusiasm for irrigation cost recovery ... [based on] a presumed link between cost recovery and better operation and maintenance', because it confirmed earlier findings by OED that 'there is normally no link between higher water charges and better operation and maintenance. Revenue from water charges generally goes to the general treasury and is not earmarked for O\&M'.

\section{'Principled Pragmatism': The Idea Comes Full Circle}

Despite the hopes vested in pricing policies during the 1990s, a number of elements have gradually made a reassessment of these expectations necessary. This readjustment has been driven not only by the recognition of a host of technical, socio-economic, legal and political difficulties, which will be analysed at length in Chapter 2, but also by the emergence of severe conflicts caused by raised water charges (or curtailed subsidies) in several countries. The question of charging for water has also suffered from an unfortunate lack of distinction between agriculture and the domestic sector, and many of the conflicts that have bedevilled the latter were mistakenly extended to the former. This may have been partly due to insufficient attention given to crucial differences between the two sectors (see Molle and Berkoff, Chapter 2, this volume), apparent in many policy and academic documents that tend to assume that the two sectors are similar.

The empirical literature on water pricing in irrigated agriculture also yields a paucity of cases in which pricing policies have successfully achieved the objectives assigned to them. First, it has been excessively difficult to raise and stabilize cost recovery from users and in most cases even O\&M expenditures are not recovered. There are, however, exceptions. Morocco and Tunisia have, for instance, been successful in covering O\&M; Mexico has turned over most of its public schemes (and their related costs) to water user associations; water charges were increased by three times in the
1997 reform of Andhra Pradesh, India, though from a very low level (Samal and Kolanu, 2004); the National Irrigation Agency in Philippines has cut its staff by $75 \%$ in the last 25 years (Oorthuizen, 2003); China is experimenting with several ways of delegating water management and strengthening incentives (see Lohmar et al., Chapter 12, this volume), etc. Not all these cases have been unmitigated successes, but they perhaps signal a trend towards better cost recovery, with financial autonomy of irrigation units or projects as a major objective.

The impact of water charges on efficiency has, in contrast, remained almost entirely elusive, as revealed by Bosworth et al.'s (2002) recent review of the literature. An analysis of the use of economic tools for demand management in Mediterranean countries also showed that their use in agriculture was far more limited than in the urban sector, and that prices alone did not suffice to elicit significant changes in behaviour (Chohin-Kuper et al., 2002). Compilations of cases such as Bhatia et al. (1995), Dinar and Subramanian (1997), Dinar (2000) and Johansson (2000) provide some evidence to the contrary but they are drawn almost exclusively from the urban water sector or from modelling exercises. Examples of changes in cropping patterns and technology are more numerous but these changes are typically caused by a host of interacting factors of which water pricing is seldom of more than marginal significance. Finally, Dinar and Saleth (2005) admit that 'efficient water pricing schemes are rare, if not completely absent, even in economically advanced regions with extreme water scarcity levels, [which] provides sufficient evidence for the persistence of a vast gap between the development of pricing theory and its practical application'; and there also appears to be no example of a country having resorted to administered price setting in order to allocate water among sectors (Bosworth et al., 2002).

A review of OECD countries (Garrido, 2002) concluded that progress in the implementation of water pricing policies had been slow and uneven, and that farmers typically paid only a fraction of O\&M costs (and nothing for rehabilitation and amortization of investments, let alone environmental or 
resource costs). 'Irrigation pricing reforms should not expect significant reductions in farmers' water consumption', and quotas ${ }^{24}$ are likely to be required, though prices are expected to contribute to the EU's environmental objective based on the polluter-pay principle (Garrido, 2002). A review of the use of economic incentives (EIs) in Canada (PRI, 2005) noted that 'there has been a tendency to promote EIs as being capable of delivering the best of all worlds: environmental protection, economic and technological development, and revenue generation, while maintaining equity, and all in one convenient box' but 'careful examination of reallife experiences' is needed before these objectives can be assumed to be achieved.

It is thus becoming apparent that on-theground evidence of the impact of economic tools remains well short of expectations and promises. Since 2000, several official documents and academic papers have scaled down the earlier enthusiasm for water pricing, reflecting not only the widening gap between theory and practice but also the wish to avoid the violent controversies around this issue (mostly it is true relating to the domestic sector). The Ministerial Declaration of the Second World Water Forum (World Water Commission, 2000) advocates a prudent 'move towards pricing water services to reflect the cost of their provision', but adds that 'this approach should take account of the need for equity and the basic needs of the poor and the vulnerable'. ${ }^{25}$ Tellingly, the word 'pricing' is absent from the Bonn Conference 27 recommendations for action, issued in December 2001.

\footnotetext{
${ }^{24} \mathrm{But}$ 'the use of quotas or allotments suggests that efficient allocation can be made without prices, and that the combination of quotas and cost-recovery charges - not including the opportunity cost of water as the European Union foresees in its Water Framework Directive - may be a viable mix of instruments' (Garrido, 2002).

${ }^{25}$ Interestingly, this political statement appears much more prudent than the World Water Council's two parallel reports prepared for the same forum: 'Making Water Everybody's Business' 'recommends that consumers be charged the full cost of providing water services' (Cosgrove and Rijsberman, 2000); see supra for quote from the report 'A water secure World' (World Water Commission, 2000).
}

Similarly, the 2002 Stockholm statement that, under the title 'Urgent action needed for water security', synthesizes the lessons from the five previous symposia lists four principles for action that do not refer to the use of economic instruments in managing water. Recently, the World Water Assessment Program (UNESCOWWAP, 2006) stressed the importance of noneconomic goals in irrigation, the potential limitations to volumetric pricing and the goal of recovering O\&M costs only.

More significantly, perhaps, a recent OED assessment of the 1993 World Bank water strategy concluded: 'Globally, most Bank projects pay lip-service to cost recovery, ${ }^{26} \ldots$ [and] too frequently, Bank water staff promote reform when the enabling conditions are absent due to the programmatic nature of projects.' In sum: 'Pricing promotes efficiency and conservation . . . but there are few successful examples because of the economic and cultural difficulties of putting a value on a natural resource' (Pitman, 2002). In 2003, the Bank issued a new water resources sector strategy (World Bank, 2003), aimed at updating the document issued 10 years earlier. It acknowledged the 'yawning gap between simple economic principles . . . and on-the-ground reality'.

\begin{abstract}
It has often been stated that having users pay 'the full cost of water' would solve these problems. Experience has shown that the situation is considerably more complex and nuanced, and that it is not enough to just extol the virtues of pricing. This section outlines a different approach - one of 'principled pragmatism.' 'Principled' because economic principles such as ensuring that users take financial and resource costs into account when using water, are very important. And 'pragmatism' because solutions need to be tailored to specific, widely varying natural, cultural, economic and political circumstances, in which the art of reform is the art of the possible.
\end{abstract}

(World Bank, 2003)

\footnotetext{
${ }^{26} \mathrm{Among}$ sectors of the water strategy whose implementation was rated as 'ineffective' were 'allocation issues and opportunity cost of water' and 'transparency and full cost accounting of water delivery service', while 'increasing user charges' was rated 'moderately effective' (Pitman, 2002).
} 
Yet, the soundness of the theoretical background is constantly reaffirmed (World Bank, 2003). ${ }^{27}$ Difficulties in implementing water pricing, however, are often ascribed to technical or cultural difficulties, and to political resistance of entrenched sectoral interests (Saleth, 2001; Dinar and Saleth, 2005), and there is a continued hankering for a more ambitious role for pricing. The most recent World Bank initiative for 'Reengaging in agricultural water management' (World Bank, 2005b), however, adopts a more balanced position and states that management of large-scale irrigation has 'been plagued by problems of irrigation service charges, both low levels of charge and low levels of collection'. Where demand is not responsive to price increases and where there is a water shortage, a case admittedly quite frequent, 'rationing (in the short term) or the allocation of quotas (for the long term) should be considered as an effective way to reduce demand and encourage efficiency' (World Bank, 2005b).

It is becoming clear that arguments have often been presented in a very broad manner, with general principles repeated without the necessary qualifications. The literature bears frequent confusion across the board between the different possible justifications for water pricing, and the theoretical arguments that may apply to a particular context are often implicitly or explicitly extended to other situations where they cease to be valid. It is evident, in particular, that there are crucial differences between domestic and irrigation water, classical large-scale surface irrigation and pump irrigation, government and farmermanaged schemes, low- and high-tech distribution systems, staple and cash-crop production, and developed and developing countries. Similarly, parallels with land rights provide limited guidance for addressing water rights (Hanemann, 2006), and comparisons between the water and the power sector can also be misleading.

On a more philosophical plan, the principle of 'water as an economic good'

\footnotetext{
${ }^{27}$ The neo-classical principles of pricing and allocation are axiomatic. If at fault, it is because of contextual factors that should be removed, not because the theory should better conform to the real world.
}

has triggered a heated debate, with the emergence of a concurrent paradigm underscoring water as a social good and/or a human right. This confrontation of world views has introduced a main fault line across the debate (ODI, 2002; Hanemann, 2006). All parties agree that water is the 'stuff of life' and, to some extent, that extravagant consumption is to blame. Those supporting 'water as an economic good', however, see waste as the result of underpricing and, consequently, pricing or markets as a way out of the crisis. They see perfect markets as an optimal means to achieve economic efficiency, as a desirable objective for the society as a whole, and alternatives as second-best options. The rationale for cost recovery, linked to the need to fund maintenance and further expand water services, is opposed by supporters of the 'water as a basic human right' paradigm, who consider that domestic supply is a right that warrants subsidized public investments. They view pricing or market instruments with suspicion, stressing that water is foremost a social good and that its allocation cannot be left to mechanisms that will eventually favour the wealthy and powerful. In their view, prices should be controlled by the government to avoid the commodification of water and the exclusion of the poorest, and only volumes beyond vital requirements should be charged (The Water Manifesto, 1999; Shiva, 2002). Here again, the debate has been obscured by an indiscriminate mix of situations, from little to very water-short regions, from domestic use to irrigation and from individual use to large public schemes.

Controversies and debates along this fault line have increased in recent years. At both extremes, rather uncompromising viewpoints have been expressed, which have not been helpful in building bridges across the two world views. They have stuck, on the one hand to market fundamentalism that seems to be impervious to the lessons of reality on the ground and, on the other, to a romantic posture where water is seen as god-given and should not be sullied by mundane issues of cash. Some, however, seek to adopt more nuanced and conciliatory stances. Despite 
such attempts to bridge conflicting viewpoints, the debate remains fairly polarized.

In the 1990s, the academic literature was dominated by theoretical considerations and promotion of economic incentives as key policy instruments to instil economic rationality and regulate the water sector. Recent publications have focused on the practical constraints faced, besides the inadequacy of some of their theoretical tenets. Without going into the details analysed by Molle and Berkoff in Chapter 2 (and illustrated in the subsequent chapters) mention should be made of the evidence provided by the case studies and literature reviews carried out by Bosworth et al. (2002), Cornish and Perry (2003), Hellegers and Perry (2004) and Cornish et al. (2004). They stress the importance of distinguishing between objectives and the design of charging systems to meet these objectives according to the context. Volumetric pricing is rare and 'the response in demand to volumetric pricing is widely shown to be minimal'. Water markets have been established in a few locations but bureaucratic allocation of water through price setting is nowhere to be observed; the debate on sectoral allocation may have been misconstrued (Savenije and van der Zaag, 2002) and the degree of misallocation overstated (Molle and Berkoff, 2006).

A balanced assessment has also been issued by ICID (2004) which does not consider recovery of the full financial costs of irrigation but emphasizes the need to define negotiated contractual relationships between providers (of any kind) and users, and to charge the latter the cost of O\&M plus renewal costs ('the sustainability costs'). 'Opportunity pricing' has no application in pricing services but the determination of all costs helps in assessing values before allocating resources. Defining quotas may hinder flexibility in reallocation but quotas are equitable and effective in managing scarcity. Dinar and Mody (2004) also observe that financial cost recovery, though becoming more common, is hard to implement. In most cases, they note, pricing does not elicit more efficient on-farm water use, and when it does (often through crop shift or technological change), it does not automatically translate into total water savings. Easter and Liu (2005) focus on cost recovery objectives, ponder on why cost recovery rates are low and acknowledge that water demand may be elastic only at levels of charge that are politically unacceptable. Emphasis is put on participatory and transparent definition of charges and on keeping them within the system, ensuring financial autonomy and enhancing accountability of managers.

In other words, a new consensus is emerging which is by and large replicating the conclusions established 20 years earlier. Charging for water is primarily a fiscal issue on which no general statement can be made as long as it is not part and parcel of a wider financing mechanism, whereby users are effectively empowered and managers made accountable through their dependency on fee collection. Other conservation and allocation objectives remain important but the effectiveness of pricing is limited to some specific 'niches', which can be made to grow but which are likely to remain limited, or marginal, in the foreseeable future. Pricing will generally have limited impact alone but is an instrument that can contribute to a package of incentives. Principled pragmatism is needed to apprehend the constraints on the ground, and sound management of supply - at all scales, from the farm to the basin - remains the unglamorous yet fundamental prerequisite to improving the performance of the water sector.

This storyline raises intriguing questions on why the debate has gone full circle in a 20-year period, going through different conflicting views, ${ }^{28}$ detours and

\footnotetext{
${ }^{28}$ As suggested along this historical review, the debate showed considerable wavering between opposite viewpoints and statements: as a rule, cost had to be recovered from users but it was proposed that this could be alternatively done by the government; only direct irrigation benefits should be considered but consideration of induced economic activities was also proposed; subsidies were acceptable and optimum might differ from long-term marginal pricing but strict endorsement of the latter principle proved persistent; the utility model was seen adequate for irrigation service but its clear limitations sometimes recognized; irrigation should be seen as any other economic activity but its other social objectives acknowledged; pricing instruments can target several goals at one time but it is not the case in most instances; etc.
} 
dead ends and finally 'rediscovering' both the limits imposed by the real world to policy instruments and the particular conditions needed for their effectiveness. Although it is not the central objective of this chapter to address this question, one may wonder whether economic thinking, coming to prominence in the late 1980s to early 1990s, has not been subjected to the excessive self-confidence that other disciplines (e.g. agronomy, water engineering, rural sociology and planning) have shown earlier, before being confronted with difficulties in raising yields, improving irrigation efficiency, setting up user groups or implementing integrated development projects or policies. Overconfidence leads to excessive faith in theoretical frameworks, and lack of attention to on-theground and political economic factors (Dinar, 2000; Green, ${ }^{29}$ 2000). Systematic stigmatization of irrigation as a wasteful sector has frequently been based on a lack of understanding of irrigation management and basin hydrology, just as the domestic and irrigation sectors have been confused, despite crucial differences. Likewise, anti-state ideological rhetoric has often supported the idea that bureaucratic water allocation is insensitive to economic rationality ${ }^{30}$ (Moore, 1990;

\footnotetext{
${ }^{29}$ Green (2000) contrasts a Panglossian (optimistic) approach with a 'Pragmatic approach, generally characterised by a concern for institutional design, for increasing public participation and a search for ways of supporting decisions with appraisal tools such as benefit-cost analysis . . . [which] lacks the self-confidence of the Panglossian approach and lacks the glorious heroism of economists riding to the rescue of water management. It is more hesitant in claiming success, hoping instead that instances offer lessons which will improve future decisions'. See also Albiac et al.'s (2006) remark that 'water pricing advocated by some government advisors and environmentalists starts to look like "armchair economics"', and Embid-Irujo (2005) on Spain in the 1990s: 'For certain economists or the intellectual colleagues of certain economists, this policy [the setting of a "real" price for water] was a sort of "magic wand" that would solve all the current problems at a stroke, while other experts were more realistic.'

${ }^{30}$ See, for example, Anderson and Snyder (1997): 'Because [water] is so precious, we cannot afford misallocation that comes from political control.'
}

Carruthers, 1997), even where evidence suggests otherwise (Molle and Berkoff, 2006). The issue of sectoral reallocation may have been inflated because of its salience in the USA and also because some economists advocate ${ }^{31}$ markets out of ideological inclination rather than sound examination of local contexts (Gaffney, 1997; Bauer, 2004). It is also apparent that the constitution of a massive body of literature, largely fed by a few mainstream institutions and overly self-referential, has contributed to mainstreaming ideas that have often been indiscriminately picked up in national universities or policies, without the necessary caveats and contextualization.

Chapter 2 is devoted to giving flesh to this narrative. It starts with some general considerations on pricing and irrigated agriculture before examining the different policy objectives that can be attained through pricing instruments. For each of these, we attempt to confront the theoretical background with field evidence and assess the scope for achieving these objectives. Getting price incentives in irrigation 'down to earth' by no means negates the importance of prices, or the crucial need for economic insight in the development of water resources. It does, however, assert that - as for all other policy instruments we should neither entertain unreasonable expectations nor justify or propose policies based on general principles that may not hold in a particular context. When there are good reasons to design financial mechanisms, it does not help to confuse objectives by bringing in arguments of limited validity. Through abundant references to the literature, we will also point to discursive and conceptual shifts and finally identify a range of conclusions which might, hopefully, be contemplated as firm ground for future policy making.

\footnotetext{
${ }^{31}$ Faith in market mechanisms for resource allocation has been "politically correct"—often approaching dogma-for more than a decade. Although attractive in principle, the complexity of establishing markets for tradable water rights should not be underestimated' (Siamwalla and Roche, 2001).
} 


\section{References}

ADB (Asian Development Bank) (1986a) Review of Bank Operations in the Irrigation Sector 1966-1985. Asian Development Bank, Manila.

ADB (1986b) Irrigation service fees. Proceedings of the Regional Seminar on Irrigation Fees, Manila, 21-25 July 1986. Asian Development Bank, Manila.

ADB (2000) Water for all: the water policy of the Asian Development Bank. Available at: http://www.adb. org/documents/policies/water/water.pdf

AfDB (African Development Bank) and ADF (African Development Fund) (2000) Policy for Integrated Water Resources Management. African Development Bank, Tunis.

Ahmad, M. (2000) Water pricing and markets in the Near East: policy issues and options. Water Policy 2(3), 229-242.

Albiac, J., Martínez, Y. and Tapia, X. (2006) Water quantity and quality issues in Mediterranean agriculture. In: Chapter 5, Water and Agriculture: Sustainability, Markets and Policies. OECD, Paris, pp. 137-156.

AMAECO and ANAFID (2002) Les Politiques D'irrigation: Considérations Micro et Macro-économiques, Vol. 4. Association Marocaine d'Agro-Economie et Association Nationale de I'Amélioration Foncière, $\mathrm{d}^{\prime}$ Irrigation et de Drainage. Agadir, Morocco.

Anderson, T.L. and Snyder, P.S. (1997) Priming the Invisible Pump. Cato Institute, Washington, DC.

Avis, C., Tydeman, C. and Gelabert, E.R. (2000) What Role for Water Pricing? Ten Actions for Internalising Sustainability. WWF International, European Freshwater Programme, Brussels.

Barker, R. and Molle, F. (2004) Evolution of Irrigation in South and Southeast Asia. IWMI Comprehensive Assessment Research Report 5. IWMI Comprehensive Assessment Secretariat, Colombo, Sri Lanka, pp. vi, 45 .

Bastiampillai, B. (1967) The revival of irrigation enterprise in Ceylon, 1870 to 1890. Ceylon Journal of Historical and Social Studies 10, 1-26.

Bauer, C.J. (2004) Siren Song: Chilean Water Law as a Model for International Reform. Resources for the Future, Washington, DC.

Bhatia, R., Cestti, R. and Winpenny, J. (1995) Water Conservation and Reallocation: Best Practice Cases in Improving Economic Efficiency and Environmental Quality. Water \& Sanitation Currents, World Bank, Washington, DC, p. v.

Bolding, A., Mollinga, P.P. and van Straaten, K. (1995) Modules for modernization: colonial irrigation in India and the technological dimension of agrarian change. Journal of Development Studies 31(6), 805-844.

Bosworth, B., Cornish, G., Perry, C. and van Steenbergen, F. (2002) Water Charging in Irrigated Agriculture: Lessons from the Literature. Report OD 145. HR Wallingford, Wallingford, UK.

Brooks, D.B. (1997) Water demand management: conceptual framework and policy implementation. In: Brooks, D.B., Rached, E. and Saade, M. (eds) Management of Water Demand in Africa and the Middle East: Current Practices and Future Needs. International Development Research Centre, Ottawa, Canada.

Carruthers, I. (1997) The water paradox: scarce and valuable but inefficient use and poor political decisions: who should we blame? In: Dupuy, B. (ed.) Aspects Economiques de la Gestion de L'eau dans le Bassin Méditerranéen. CIHEAM-IAMM, Bari, Italy, pp. 125-135.

Carruthers, I. and Clarck, C. (1981) The Economics of Irrigation. Liverpool University Press, Liverpool, UK.

Carruthers, I.D. and Morrisson, J.A. (1996) Institutions in water resources management: insights from new institutional economics. In: Howsam, P. and Carter, R.C. (eds) Water Policy: Allocation and Management in Practice. E \& FN Spon, London, pp. 205-212.

Carruthers, I.D., Peabody, N.S.III, Bishop, A.A., LeBaron, A.D., Mehra, R., Ramchand, O., Peterson, D. and Wood, D.H. (1985) Irrigation Pricing and Management. Report to USAID. DEVRES, Washington, DC.

CEPAL (Comisión Económica para América Latina y el Caribe) (1995) Mercados de Derechos de Agua: entorno Legal. CEPAL, Santiago de Chile.

Chakravorty, N. (2004) Water pricing in Bangladesh: a pro-poor framework based on two surface water irrigation projects in Bangladesh. Draft.

Chaudhry, M.G., Majid, S.A. and Chaudhry, G.M. (1993) The policy of irrigation water pricing in Pakistan: aims, assessment and needed redirections. The Pakistan Development Review 32(4) Part II, 809-821.

Chohin-Kuper, A., Rieu, T. and Montginoul, M. (2002) Economic tools for water demand management in the Mediterranean. Forum on 'Progress in Water Demand Management in the Mediterranean'. Fiuggi, 3-5 October 2002.

Cornish, G., Bosworth, B., Perry, C. and Burke, J. (2004) Water Charging in Irrigated Agriculture: An Analysis of International Experience. FAO Waters Reports 28. FAO, Rome, Italy. 
Cornish, G.A. and Perry, C.J. (2003) Water Charging in Irrigated Agriculture: Lessons from the Field. Report OD 150. HR Wallingford, Wallingford, UK.

Cosgrove, W.J. and Rijsberman, F.R. (2000) World Water Vision: Making Water Everybody's Business. Earthscan, London.

Coward, E.W. (1980) Irrigation and Agricultural Development in Asia. Cornell University Press, Ithaca, New York.

de Moor, A. and Calami, P. (1997) Subsidizing Unsustainable Development: Undermining the Earth with Public Funds. Earth Council, San Jose, Costa Rica.

Dinar, A. (1998) Water policy reforms: informational needs and implementation obstacles. Water Policy1(4), 367-382.

Dinar, A. (ed.) (2000) The Political Economy of Water Pricing Reforms. OUP, for the World Bank, New York.

Dinar, A. and Mody, J. (2004) Irrigation water management policies: allocation and pricing principles and implementation experiences. Natural Resources Forum 28, 112-122.

Dinar, A. and Saleth, R.M. (2005) Issues in water pricing reforms: from getting correct prices to setting appropriate institutions. In: Folmer, H. and Tietenberg, T. (eds) The International Yearbook of Environmental and Resource Economics 2005/2006. Edward Elgar, Cheltenham, UK.

Dinar, A. and Subramanian, A. (1997) Water Pricing Experiences: An International Perspective. World Bank Technical Paper No. 386. World Bank, Washington, DC.

Duane, P. (1986) Cost recovery in irrigation projects: perceptions from World Bank operation evaluation. In: FAO, Land and Water Development Division and USAID, Water Management Synthesis II Project. Technical papers from the Expert Consultation on Irrigation Water Charges, Vol. I, Rome, 22-26 September 1986. FAO, Rome, Italy, pp.122-157.

Easter, K.W. and Liu, Y. (2005) Cost Recovery and Water Pricing for Irrigation and Drainage Projects. Agriculture and Rural Development Discussion Paper No. 20. World Bank, Washington, DC.

Easter, K.W., Rosegrant, M.W. and Dinar, A. (eds) (1998) Markets for Water: Potential and Performances. Kluwer Academic Publishers, Boston, Massachusetts.

Easter, K.W., Rosegrant, M.W. and Dinar, A. (1999) Formal and informal markets for water: institutions, performance and constraints. The World Bank Research Observer 14(1), 99-116.

Embid-Irujo, A. (2005) Water pricing in Spain. International Journal of Water Resources Development 21(1), $31-41$.

ESCAP (Economic and Social Commission for Western Asia) (1981) Proceedings of the Expert Group Meeting on Water Pricing, held at Bangkok, Thailand, 13-19 May 1980. ESCAP Water Resources Series No. 55. UN, New York.

ESCAP (1996a) Guidelines for the Establishment of Irrigation Water Pricing Policies and Structures. ST/ ESCAP/1733. Economic and Social Commission for Asia-Pacific, Bangkok.

ESCAP (1996b) Overview of Water Pricing Policies and Structures in the ESCAP Region. ST/ESCAP/1646. Economic and Social Commission for Asia-Pacific, Bangkok.

ESCWA (Economic and Social Commission for Western Asia) (1997) Review of the Impact of Pricing Policy on Water Demand in the ESCWA Region, with a Case Study on Jordan. (E/ESCWA/ENR/1997/6), Beirut.

ESCWA (2005) Module Ten: Valuing Water Resources. Workshop on 'Training of Trainers on the Application of IWRM Guidelines in the Arab Region' Kuwait, 14-18 May 2005. ESCWA, Beirut.

EU (European Union) (2000) Communication from the Commission to the Council, The European Parliament and The Economic and Social Committee: Pricing Policies for Enhancing the Sustainability of Water Resources. COM(2000) 477 final, European Union, Brussels.

European Commission (2000a) The Environmental Impacts of Irrigation in the European Union. A Report to the Environmental Directorate of the European Commission, Brussels.

European Commission (2000b) Pricing Policies for Enhancing the Sustainability of Water Resources. Communication from the Commission to the Council, The European Parliament, and The Economic and Social Committee. COM(2000) 477 final, Brussels.

EU-WATECO (2003) Common Implementation Strategy for the Water Framework Directive (2000/60/ EC). Guidance Document No 1: Economics and the Environment - The Implementation Challenge of the Water Framework Directive. Produced by Working Group 2.6 - WATECO. European Union, Brussels.

Falkenmark, M. (2001) The greatest water problem: the inability to link environmental security, water security and food security. International Journal of Water Resources Development 17(4), 539-554.

FAO (1996a) Malaysia. Available at: http://www.fao.org/ag/agl/aglw/aquastat/countries/malaysia/index.stm 
FAO and USAID, Water Management Synthesis II Project. (1986) Report on The Expert Consultation on Irrigation Water Charges, Rome 22-26 September 1986. FAO, Rome, Italy.

Farmer, B.H. (1976) Pioneer Peasant Colonization in Ceylon: A Study in Asian Agrarian Problems. Greenwood Press Publishers, Connecticut.

Frank, A. (2001) World has enough water for all, experts say: but only if people pay. National Geographic News, 1 May 2001.

Frederick, K.D. (1993) Balancing Water Demands with Supplies: The Role of Management in a World of Increasing Scarcity. World Bank Technical Paper 189. World Bank, Washington, DC.

Frederiksen, H.D. (1986) Organizing for O\&M and Charges for Service. Office Memorandum. World Bank, Washington, DC.

Gaffney, G. (1997) What price water marketing? California's new frontier - Special Issue: commemorating the 100th Anniversary of the Death of Henry George. American Journal of Economics and Sociology.

Garrido, A. (2002) Transition to Full-Cost Pricing of Irrigation Water for Agriculture in OECD Countries. OECD, Environment Directorate, Paris.

Ghate, P. (1985) Some principles relevant to fixing the level of irrigation charges in bank projects. Asian Development Bank, Economic Office, Manila. Inter-office Memorandum. Draft.

Gleick, P. (2001) Making every drop count. Scientific American, February 2001.

Gleick, P.H. (2003) Global freshwater resources: soft-path solutions for the 21 st century. Science 302, 1524-1528.

GOI (Government of India, Ministry of Water Resources) (2002) National Water Policy. New Delhi, April 2002.

GOP (Government of Pakistan) (2002) National Water Policy. Islamabad, Pakistan.

Government of Bangladesh (1999) National water policy. Available at: http://www.comnet.mt/bangladesh/ NWtrPol.htm

Government of Brazil (1997) Política e sistema nacional de gerenciamento de recursos hídricos Lei Federal $\mathrm{N}^{\circ}$ 9.433, 8 January 1997.

Green, C. (2000) If only life were that simple: optimism and pessimism in economics. Physics and Chemistry of the Earth 25(3), 205-212.

Hamdy, A., Abu-Zeid, M. and Lacirignola, C. (1995) Water crisis in the Mediterranean: agricultural water demand management. Water International 20(4), 176-187.

Hanemann, W.H. (2006) The economic conception of water. In: Rogers, P.P., Llamas, M.R. and MartinezCortina, L. (eds) Water Crisis: Myth or Reality? Taylor \& Francis, London.

Hellegers, P.J.G.J. and Perry, C.J. (2004) Water as an Economic Good in Irrigated Agriculture: Theory and Practice. Agricultural Economics Research Institute, The Hague, The Netherlands.

Hodge, I.D. and Adams, W.M. (1997) Allocating water for production and rural conservation: choices and institutions. In: Kay, M., Franks, T. and Smith, L. (eds) Water: Economics, Management and Demand. E \& FN Spon, London, pp. 117-127.

IADB (Inter-American Development Bank) (1998) Strategy for Integrated Water Resources Management. IADB, Washington, DC.

ICID (International Commission on Irrigation and Drainage) (2004) Irrigation and Drainage Services: Some Principles and Issues towards Sustainability. An ICID Position Paper. ICID, New Delhi.

IRRI (1995) Water: A Looming Crisis. IRRI, Los Baños, Philippines.

Johansson, R.C. (2000) Pricing Irrigation Water: A Literature Survey. World Bank, Washington, DC.

Johansson, R.C., Tsur, Y., Roe, T.L., Doukkali, R. and Dinar, A. (2002) Pricing irrigation water: a review of theory and practice. Water Policy 4(2), 173-199.

Jones, T. (2003) Pricing water. OECD, Environment Directorate, Paris.

Jones, W.I. (1995) The World Bank and Irrigation. Operations Evaluation Department, a World Bank Operation Evaluation Study. World Bank, Washington, DC.

Kaika, M. (2003) The water framework directive: a new directive for a changing social, political and economic European Framework. European Planning Studies 1(3), 299-313.

Khanna, G. and Sheng, F. (2000) Towards full-cost pricing of water. WWF Conservation Economics Unit.

Kim, C.S. and Schaible, G.D. (2000) Economic benefits resulting from irrigation water use: theory and an application to groundwater use. Environmental and Resource Economics 17, 73-87.

Krueger, A.O., Schiff, M. and Valdés, A. (1988) Agricultural incentives in developing countries: measuring the effect of sectoral and economywide policies. World Bank Economic Review 2(3), 255-271.

Krueger, A.O., Schiff, M. and Valdés, A. (eds) (1991) The Political Economy of Agricultural Pricing Policy. A World Bank Comparative Study. Johns Hopkins University Press, Baltimore, Maryland. 
Lavelle, M. and Kurlantzick, J. (2002) The Coming Water Crisis. Resources for the Future, Washington, DC.

Le Moigne, G., Easter, K.W., Ochs, W.J. and Giltner, S. (1994) Water Policy and Water Markets. World Bank, Technical Paper No. 249. World Bank, Washington, DC.

Louw, D.B. and Kassier, W.E. (2002) The Costs and Benefits of Water Demand Management. Centre for International Agricultural Marketing and Development, Paarl, South Africa.

Maestu, J. (2001) The political economy of the implementation of changes in pricing practices in Spain. What can we learn? In: Pricing Water, Economics, Environment and Society. Conference Proceedings, Sintra, European Commission, Brussels, pp. 247-267.

Molden, D., Frenken, K., Barker, R., de Fraiture, C., Mati, B., Svendsen, M., Sadoff, C. and Finlayson, M. (2007) Trends in water and agricultural development. In: Molden, D. (ed.) Water for Food - Water for Life, Chapter 4. Comprehensive Assessment of Water Management in Agriculture. EarthScan, London.

Molle, F. and Berkoff, J. (2006) Cities versus Agriculture: Revisiting Intersectoral Water Transfers, Potential Gains and Conflicts. IWMI Comprehensive Assessment Research Report 10. IWMI Comprehensive Assessment Secretariat, Colombo, Sri Lanka, p. vi.

Molle, F. and Renwick, M. (2005) Economics and Politics of Water Resources Development: Uda Walawe Irrigation Project, Sri Lanka. IWMI Research Report 87. IWMI, Colombo, Sri Lanka, p. vi.

Moore, M. (1989) The fruits and fallacies of neoliberalism: the case of irrigation policy. World Development $17(11), 1733-1750$.

Moore, M. (1990) The rational choice paradigm and the allocation of agricultural development resources. Development and Change 21, 225-246.

Morris, J. (1996) Water policy: Economic theory and political reality. In: Howsam, P. and Carter, R.C. (eds) Water Policy: Allocation and Management in Practice. E \& FN Spon, London, pp. 228-234.

ODI (Overseas Development Institute) 2002. The 'Water Crisis': Faultlines in Global Debates. ODI Briefing Paper. ODI, London. Available at: http://www.odi.org.uk/

OECD (1999a) Future water resources: towards a demand-side solution? Highlight of the OECD Information Base. Available at: www.oecd.org/sge/au/highlight16.html

OECD (1999b) The price of water. Trends in OECD countries. OECD, Paris, p.173.

O'Mara, G.T. (1990) Making Bank Irrigation Investments More Sustainable (It is time to rationalize policy guidelines on Bank irrigation projects). Agriculture and Rural Development Department. Working Paper. World Bank, Washington, DC.

Oorthuizen, J. (2003) Water, Works, and Wages: The Everyday Politics of Irrigation Management Reform in the Philippines. Wageningen University Water Resources Series. Orient Longman, Hyderabad, India.

Perry, C.J. (1996) Alternative to Cost Sharing for Water Service to Agriculture in Egypt. IIMI Research Report No. 2. IIMI, Colombo, Sri Lanka.

Perry, C.J. (2001a) Water at any price? Issues and options in charging for irrigation water. Irrigation and Drainage 50(1), 1-7.

Perry, C.J. (2001b) Charging for Irrigation Water: The Issues and Options, with a Case Study from Iran. Research Report No. 52. IWMI, Colombo, Sri Lanka.

Perry, C.J., Rock, M. and Seckler, D. (1997) Water as an Economic Good: A Solution, or a Problem? Research Report No. 14. IWMI, Colombo, Sri Lanka.

Pitman, G.K. (2002) Bridging Troubled Water: Assessing the World Bank Water Resource Strategy. World Bank Operations Evaluation Department. World Bank, Washington, DC.

PRI (Policy Research Initiative) (2005) Economic Instruments for Water Demand Management in an Integrated Water Resources Management Framework. Government of Canada, Ottawa.

Rao, P.K. (1984) Comment on cost recovery and irrigation water pricing. In: ODI Irrigation Management Network Paper. Overseas Development Institute, London.

Ray, A., Bruce, C. and Hotes, F.L. (1976) Cost recovery policies for irrigation projects: informal guidelines. Paper presented for informal guidance of persons involved in cost recovery policies for irrigation projects. World Bank, Washington, DC.

Repetto, R. (1986) Skimming the Water: Rent Seeking and the Performance of Public Irrigation Systems. Research Report 4. World Resource Institute, Washington, DC.

Republic of South Africa, Department of Water Affairs and Forestry (1998) National water resource strategy. Available at: http://www.dwaf.gov.za/Documents/Policies/NWRS/Default.htm

Rosegrant, M.W. and Cline, S. (2002) The politics and economics of water pricing in developing countries. Water Resources Impact 4(1), 6-8.

Rosegrant, M.W., Cai, X. and Cline, S.A. (2002) Global Water Outlook to 2005: Averting an Impending Crisis. IFPRI, Washington, DC; IWMI, Colombo, Sri Lanka, p. V. 
Saleth, R.M. (2001) Water Pricing: Potential and Problems. Policy Brief Focus 9. International Food Policy Research Institute, Washington, DC.

Samal, C.K. and Kolanu, T. (2004) Water pricing and decentralized irrigation management in Andhra Pradesh: schism between objectives and realities. Paper presented at the 'Deutscher Tropentag', Berlin.

Sampath, R.K. (1992) Issues in irrigation pricing in developing countries. World Development 20(7), 967-977.

Savenije, H.H.G. and van der Zaag, P. (2002) Water as an economic good and demand management: paradigms and pitfalls. Water International 27(1), 98-104.

Shiva, V. (2002) Water Wars: Privatization, Pollution, and Profit. Pluto Press, London.

Siamwalla, A. and Roche, F. (2001) Irrigation management under resource scarcity. In: Siamwalla, A. (ed.) The Evolving Roles of the State, Private, and Local Actors in Rural Asia: Study of Rural Asia. Oxford University Press, Hongkong, pp. 183-212.

Small, L.E. (1990) Financial tools for improving irrigation performance. In: Sampath, R.K. and Young, Robert A. (eds) Social, Economic, and Institutional Issues in Third World Irrigation Management. Westview Press, Boulder, Colorado, pp. 147-268.

Small, L.E. and Carruthers, I. (1991) Farmer-financed Irrigation: The Economics of Reform. Published in association with the International Irrigation Management Institute. Cambridge University Press, Cambridge.

Small, L.E., Adriano, M.S. and Martin, E.D. (1986) Regional study on irrigation service fees: final report. Report submitted to the Asian Development Bank. IIMI, Colombo, Sri Lanka.

Steele, T. (1867) Report on the Hambantota District. Administration Reports, 1867. Ceylon Government Press, Colombo, Sri Lanka.

Stone, I. (1984) Canal Irrigation in British India: Perspective on Technological Change in a Peasant Economy. Cambridge University Press, Cambridge.

Svendsen, M. (1986) Irrigation system recurrent cost recovery: a pragmatic approach. In: FAO. Land and Water Development Division; USAID. Water Management Synthesis II. Project Technical papers from the Expert Consultation on Irrigation Water Charges, Vol. I, Rome, 22-26 September 1986. FAO, Rome, Italy, pp. 122-157.

Teerink, J.R. and Nakashima, M. (1993) Water Allocation, Rights, and Pricing: Examples from Japan and the United States. World Bank Technical Paper No. 198. World Bank, Washington, DC.

The Economist (2003) Priceless. Available at: http://www.economist.com/displaystory.cfm?story_id = 1906846

The Water Manifesto (1999) Available at: www.f1boat.com/99/watermanifesto.html

Thobani, M. (1997) Formal water markets: why, when and how to introduce tradable water rights. The World Bank Research Observer 12(2).

Tsur, Y. and Dinar, A. (1995) Efficiency and Equity Considerations in Pricing and Allocating Irrigation Water. Policy Research Working Paper 1460. World Bank, Washington, DC.

UNESCO (2000) Director-general sounds the alarm over looming water crisis. Available at: www.waternunc. com/gb/ungb04.thm [accessed August 2002].

UNESCO-WWAP (2006) Water: A Shared Responsibility. The United Nations World Water Development Report 2. UNESCO, Paris.

United Nations (Department of Economic and Social Affairs) (1992) Agenda 21. Available at: http://www. un.org/esa/sustdev/documents/agenda21/english/agenda21 toc.htm

Vaidyanathan, A. (Chair) (1992) Report of the Committee on Pricing of Irrigation Water. Planning Commission, Government of India, New Delhi. Reproduced in Indian Journal of Agricultural Economics 49(1), 107-133, January-March 1994.

Winpenny, J.T. (1997) Demand management for efficient and equitable use. In: Kay, M., Franks, T. and Smith, L. (eds) Water: Economics, Management and Demand. E \& FN Spon, London, pp. 296-303.

Wolfensohn, J.D. (2000) Remarks at the Second World Water Forum: 'From Vision to Action'. The Hague, The Netherlands, 22 March 2000.

World Bank (1976) Irrigation Water Charges, Benefit Taxes and Cost Recovery Policies. Central Projects Memorandum (CYM) No. 8.4. World Bank, Washington, DC.

World Bank (1980) Irrigation Water Charges, Benefit Taxes and Cost Recovery Policies. Central Projects Memorandum (CYM) No. 2.10. World Bank, Washington, DC. (reedition of No. 8.4 with little modification)

World Bank (1981) Water Management in Bank-supported Irrigation Project Systems: Analysis of Past Experiences. Report No. 3421. Operations Evaluation Department. World Bank, Washington, DC.

World Bank (1984) Financing Operation and Maintenance in Irrigation. Agriculture and Rural Development Department. World Bank, Washington, DC.

World Bank (1986) World Bank Lending Conditionality: A Review of Cost Recovery in Irrigation Projects. Report No. 6283. Operations Evaluation Department, World Bank, Washington, DC.

World Bank (1993) Water Resources Management: A World Bank Policy Paper. World Bank, Washington, DC. 
World Bank (2003) World Bank Water Resources Sector Strategy: Strategic Directions for World Bank Engagement. World Bank, Washington, DC.

World Bank (2005a) Priority issues for Indonesian agriculture. Policy Briefs. Available at: http://www.worldbank. or.id-January 2005

World Bank (2005b) Reengaging in Agricultural Water Management: Challenges, Opportunities, and TradeOffs. Water for Food Team, Agriculture and Rural Development Department (ARD). World Bank, Washington, DC.

World Bank (1978) Bangladesh: Irrigation Water Charges. A discussion paper with proposals for action to develop an irrigation water charge policy. World Bank, Washington, DC, p. 56.

World Water Commission (2000) A Water Secure World: Vision for Water, Life, and the Environment. World Water Vision Commission Report. World Water Commission, The Hague, The Netherlands. 